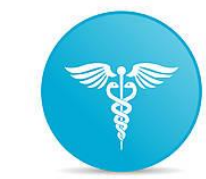

International Journal of Advances in Pharmacy and Biotechnology

Vol.4, Issue-1, 2018, 23-30

ISSN: 2454-8375

Research Article

I J A P B

Open Access

\title{
ISOLATION, CHARACTERIZATION, ANALYSIS AND STABILITY STUDY OF SOYA PROTEINS IN SIMULATED FLUIDS
}

\author{
Akshaykumar Bhasme, Tanuja Jadhav, *Sadaf Mutwalli, Swapnil Jadhav \\ Department of Pharmaceutical Chemistry, Bharati Vidyapeeth College of Pharmacy, Near \\ Chitranagari, Kolhapur -416013. \\ *Corresponding author e-mail: sadafmutwalli@rediffmail.com
}

Received: 6 February 2018

Revised: 26 February 2018

Accepted: 10 March 2018

\begin{abstract}
:
The soyabean is an important dietary component which contains abundant amount of proteins or amino acids required by human body for normal growth and maintenance. In this project, isolation of soya proteins is carried out by extraction with $0.01 \mathrm{~N}$ sodium bicarbonate and thereafter homogenization, centrifugation and dialysis of extract against Tris buffered saline solution ( $\mathrm{pH}$ 8.8). These proteins are characterized qualitatively by electrophoresis and quantitatively by Biuret assay method. Biuret assay method effectively quantifies the amount of protein in a given sample. Amino acids present in the isolated protein were identified and quantified using standard or marker amino acids. The stability study of isolated soya proteins is carried out in simulated gastric fluid (SGF) and simulated intestinal fluid (SIF), prepared according to protocol specified in USP. These proteins were quantified by Biuret assay method after respective time interval in above specified fluids. The soya proteins are found to hydrolyze in SGF after 5 minutes and in SIF within one hour. Thus in-vitro stability study of proteins in simulated fluids is an effective approach and alternative to animal model for bio-stability assessment.
\end{abstract}

Key words: Stability of soya protein; Simulated Intestinal Fluid; Simulated Gastric Fluid; soya bean

\section{INTRODUCTION}

Gross chemical composition of food includes cereals and cereal products, legumes and oil seeds, fruits and vegetables, meat, fish and their products, milk and dairy products. Composition of food constituents includes proteins, carbohydrates, lipids, enzymes, water and minerals. Among all the ingredients present in food, proteins are an essential nutrient for humans as they play an important role in the structure and function of living organisms. Proteins are available from different food sources such as seafood, white-meat poultry, milk, cheese, yogurt, eggs, beans, pork tenderloin, soy, lean beef. [1]

Soya bean is the most commonly consumed crop in the world as it contains approximately $40 \%$ protein, $35 \%$ carbohydrate, $20 \%$ lipid, $5 \%$ ash. Soy protein is a 'complete protein' as it provides all essential amino acids for human nutrition like lysine and methionine.[2] United States Food and Drug Administration approved the claim that $25 \mathrm{~g}$ of soy protein in a day, as a part of diet low in saturated fat and 
cholesterol, may reduce the risk of heart disease. This was done by different long-term studies on the effect of soy protein on cardiovascular diseases. [3] In addition to that they have also shown antihypertensive activity, antihyperlipidemic activity, prevention against osteoporosis, cancer. [3, 4] Soya protein needs to go through thermal treatment to inactivate anti-nutritive factors such as trypsin inhibitor. Jookyeong Lee optimized the hydrolysis conditions of soy protein for enhanced solubility, thermal stability and bioactivity, maintaining low degree of hydrolysis (DH); in that they determined the solubility and thermal stability in solution of hydrolysates and soy protein isolate at different protein concentrations. Hydrolysis affects thermal stability of soya protein at $\mathrm{pH} 4.5$ and below pH 3.5; soya protein hydrolysates displaced greater and lower heat stability respectively in comparison to soya protein isolates. [5] In this project, stability studies of soya proteins in simulated gastric and intestinal fluids were carried out so as to identify their metabolism profile in stomach and intestine and thereby compare it with in vivo study data.

\section{MATERIALS AND METHODS}

Materials - Sodium bicarbonate $\left(\mathrm{NaHCO}_{3}\right)$, Sodium chloride $(\mathrm{NaCl})$ were purchased from Merck Life Science private limited. TRIS buffered saline $\mathrm{pH}$ 8.8, Pepsin and Pancreatin were obtained from Himedia, Monobasic Potassium Phosphate was purchased from Loba Chemie Pvt. Ltd.

Instruments - UV-Visible Spectrophotometer (Jasco model V- 530), Electrophoresis (Biotech $\mathrm{R}$ and $\mathrm{D}$ laboratories) Centrifuge (Remi Manufacturer, Model No- C- 851/8)

\subsection{Preparation of TRIS buffer saline solution -} Accurately $6.05 \mathrm{gm}$ of TRIS and $8.76 \mathrm{gm}$ of sodium chloride was dissolved in $800 \mathrm{ml}$ of distilled water. The $\mathrm{pH}$ was adjusted with $1 \mathrm{M}$ $\mathrm{HCl}$ and the volume was made up to 1 liter with distilled water. This solution remains stable for 3 months at $40^{\circ} \mathrm{C}$.

\subsection{Extraction process of soyabean}

Soyabeans were crushed and extracted using $0.01 \mathrm{~N} \mathrm{NaHCO}$. The solution was centrifuged at $2000 \mathrm{rpm}$ for $5 \mathrm{~min}$. Lipids were extracted with chloroform and dialysis was carried out against TRIS buffer saline (pH 8.8) using membrane space (10000 kg Dalton), in which the protein was released into buffer solution.

\subsection{Quantitative Analysis of protein}

Preparation of biuret reagent - Copper Sulphate (1.50 gm) was dissolved in $250 \mathrm{ml}$ of water and sodium potassium tartarate (4.5 gm) and potassium iodide (2.5 gm) were added to it. To this solution, $6 \mathrm{M}, 50 \mathrm{ml}$ sodium hydroxide was added and the volume were adjusted to $500 \mathrm{ml}$ with water.

Biuret assay - The solutions were prepared for assay as per quantity, specified in Table No 1 . The volume was made up to $10 \mathrm{ml}$ with 
water. These solutions were analyzed in a UVVisible spectrophotometer at $624 \mathrm{~nm}$ wavelength. Using same protocol, quantitative analysis of soya protein of unknown concentration may be performed. Preparation of Buffer solution - Dipotassium hydrogen phosphate (1.452 gm), sodium dihydrogen phosphate $(7.601 \mathrm{gm})$ and sodium chloride (4.8 gm) were dissolved in sufficient water to produce 1 litre of solution. Electrophoresis - Sufficient amount of buffer solution was poured in the compartment. Whatman filter paper No.1 was cut into strips having a length of $35 \mathrm{~cm}$ and width of $5 \mathrm{~cm}$. A spot of sample was applied on a strip of filter paper and marked with pencil. The strips were dipped in buffer solution in such a way that both ends of the paper were in contact with solution. The electrodes were adjoined to compartments; current was allowed to flow (3.2 volts $/ \mathrm{cm}$ ) and electrophoresis was performed for 16 to 18 hours. The strips of filter paper were dried at $100-110^{\circ} \mathrm{C}$ for 30 min, spots were observed by spraying ninhydrin reagent and their distances were recorded.

Standard amino acid solutions were similarly run on Whatman filter paper and Rf values were recorded.

Simulated Intestinal Fluid - Monobasic potassium phosphate (6.8 gm) was dissolved in $250 \mathrm{ml}$ of water; $77 \mathrm{ml}$ of $0.2 \mathrm{~N}$ Sodium hydroxide and $500 \mathrm{ml}$ of hydrochloric acid were added. To this solution, $10 \mathrm{gm}$ of pancreatin was added and $\mathrm{pH}$ was adjusted to 6.8 by adding $0.2 \mathrm{~N}$ sodium hydroxide or 0.2 $\mathrm{N}$ hydrochloric acid. The volume was adjusted to $1000 \mathrm{ml}$ with water.

Simulated Gastric Fluid - Sodium chloride (2 gm) and pepsin (3.2 gm) were added to $7 \mathrm{ml}$ of hydrochloric acid. The $\mathrm{pH}$ was adjusted to 1.2 and the volume was made up to $1000 \mathrm{ml}$. Stability Study of Soya Protein in SGF and SIF The stability study of soya proteins was carried out in SGF and SIF over a period of time. Its stability was measured at different intervals of time (as in minutes), 0 min, 5 min, $10 \mathrm{~min}, 15 \mathrm{~min}, 30 \mathrm{~min}, 60 \mathrm{~min}$. and in hours at 0 hour, 1 hour, 2 hour, 3 hour, and 4 hour. The content of soy protein present in simulated gastric fluid and simulated intestinal fluid was quantified by using Biuret test as specified above.

\section{RESULTS AND DISCUSSION}

Human diet comprises of carbohydrates, fats, proteins, vitamins, minerals and water. Each of it has its own significance in our body hence it becomes necessary to provide it the required amount. Out of these components, proteins are important structural and functional units of human body. Proteins have diverse varieties of biological actions in human body. These proteins are important biochemical catalysts in the human body and study of these has prime importance in scientific research. 
These soya proteins are important regulators in pathogenesis of cancer, osteoporosis and menopausal disorders in females. The soya proteins are hydrolyzed in human body in the gastrointestinal tract and may be absorbed along the GIT at different rates. These proteins are hydrolyzed by peptidases and proteases in GIT. Hence it becomes necessary to study stability of these proteins in biological fluids like GI fluids. To carry out this study, it becomes necessary to use animal model and hence it becomes necessary to carry out stability study of these proteins in in-vitro protocols.

\subsection{Extraction of soyabean proteins}

All the diet used for Soya proteins have their iso-electric $\mathrm{pH}$ value on the acidic side, hence these are extracted using sodium bicarbonate solvent. Thereafter this extract was treated with chloroform so as to remove fatty acids and other hydrophobic materials in extract. Thereafter the aqueous layer was partitioned using a dialysis membrane of $10000 \mathrm{kD}$ using TRIS buffer solution. The proteins diffuse across the dialysis membrane into TRIS buffer solution. The proteins in TRIS buffer were thereafter used for further analysis.

\section{Quantitative analysis of soya protein}

The soya proteins are quantifiable by Biuret assay protocol and it has been found effective for accurate and precise quantitative estimation of soya proteins.
Regression line equation was used for determining unknown concentration of soya proteins and calibration curve of isolated protein shown in Fig. 1.

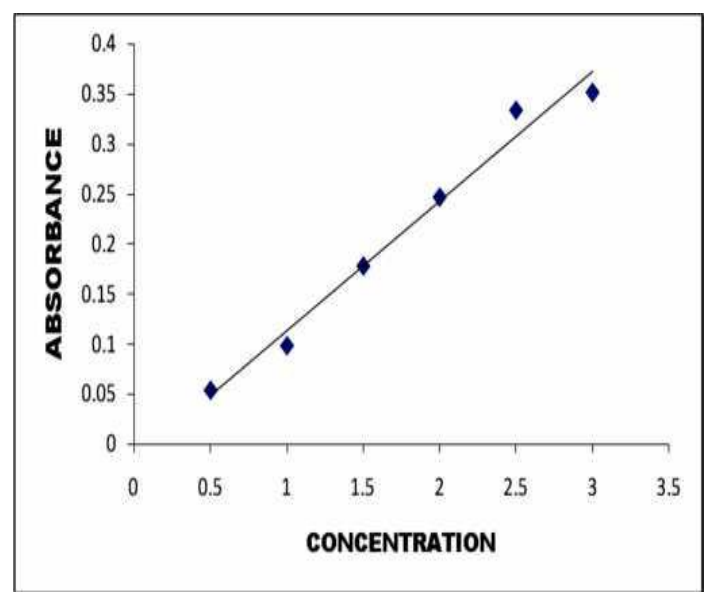

Fig. 1: Calibration Curve of Isolated Soya Protein by Biuret Assay

Table 1: Biuret assay method

\begin{tabular}{cccc}
\hline S.No. & $\begin{array}{c}\text { BSA conc } \\
\text { (mg/ml) }\end{array}$ & $\begin{array}{c}\text { BSA Stock } \\
\text { (ml) }\end{array}$ & $\begin{array}{c}\text { Biuret } \\
\text { reagent } \\
\text { (ml) }\end{array}$ \\
\hline 1 & 0 & 0 & 2 \\
2 & 1 & 0.1 & 2 \\
3 & 2 & 0.2 & 2 \\
4 & 3 & 0.3 & 2 \\
5 & 4 & 0.4 & 2 \\
6 & 5 & 0.5 & 2 \\
7 & Sample 1 ml & - & 2 \\
\hline
\end{tabular}

Table 2: Quantitative analysis of soya protein by Biuret test

\begin{tabular}{|c|c|c|c|}
\hline S.No & $\begin{array}{l}\text { Test } \\
\text { Solution } \\
\text { (ml) }\end{array}$ & $\begin{array}{c}\text { Absor- } \\
\text { bance }\end{array}$ & $\begin{array}{c}\text { Equation of line for } \\
\text { Quantitative } \\
\text { Estimation }\end{array}$ \\
\hline 1. & 1 & 0.053 & \multirow{6}{*}{$\begin{array}{c}\text { Absorbance }= \\
\text { slope }{ }^{*} \text { concentration }+ \\
\text { Intercept } \\
\text { Absorbance }= \\
0.064914^{*} \text { Concentration } \\
+(-0.01687)\end{array}$} \\
\hline 2. & 2 & 0.098 & \\
\hline 3. & 3 & 0.178 & \\
\hline 4. & 4 & 0.247 & \\
\hline 5. & 5 & 0.334 & \\
\hline 6. & 6 & 0.352 & \\
\hline
\end{tabular}


From literature survey, it has been found that following amino acids are present in soya proteins. Hence using standard amino acids as markers, the distance travelled by each amino acid was determined and sample solution of soya proteins was also processed for electrophoresis by same method. Thus it has been found that extracted soya proteins contain same amino acids as reported in literature. Arginine, Histidine, Lysine, Tyrosine, Tryptophan, Phenylalanine, Cystine,
Methionine, Threonine, Leucine, Isoleucine, Valine, Glutamic acid, Aspartic acid After literature review, it has been found that most of in-vitro assay protocols have made use of SGF and SIF, official in U.S.P. and results of these in-vitro assays matches with in-vivo studies. Hence in this protocol, we have made use of SGF and SIF, official in U.S.P. The stability study of soya proteins was carried out in SGF and SIF over a period of time specified in following table.

Table 3: Stability study of soya protein in SGF and SIF

\begin{tabular}{cccc}
\hline \multicolumn{2}{c}{ Stability in SGF and SIF } & \multicolumn{2}{c}{ Stability in SGF and SIF } \\
\hline Time (min) & $\begin{array}{c}\text { Percent } \\
\text { concentration } \\
\text { of soya protein }\end{array}$ & Time (hour) & $\begin{array}{c}\text { Percent } \\
\text { concentration } \\
\text { of soya protein }\end{array}$ \\
\hline 0 & 100 & 0 & 100 \\
5 & 91 & 1 & 96 \\
10 & 72 & 2 & 67 \\
15 & 59 & 3 & 61 \\
30 & 43 & 4 & 63 \\
60 & 38 & & \\
\hline
\end{tabular}




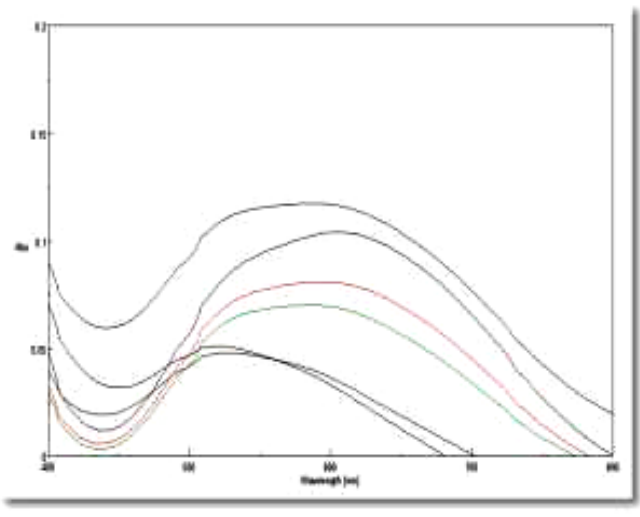

SGF (Zero hour to One hour)

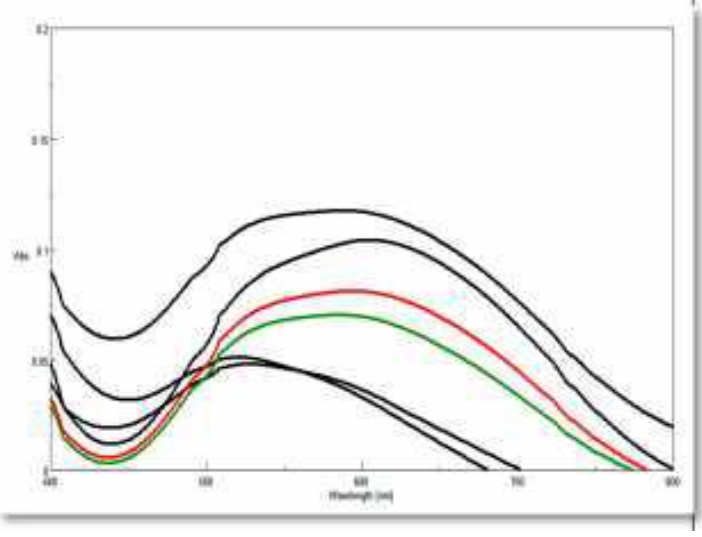

SIF (One hour to 5 hour)

Fig. 2: Overlain Spectrum of Soya Protein Stability Studies

It has been observed that soya proteins are stable in SGF up to 5 minutes and thereafter these will be hydrolyzed and hence found unstable as indicated by their decreasing concentration with increase in time in SGF as well as in overlain spectra of soya proteins concentration over the period of time. The concentration of proteins is determined by Biuret assay protocol specified above.

Similarly soya proteins were stable in SIF up to 1 hour and unstable thereafter as indicated in table no. 3 as well as in overlain spectra of soya proteins concentration over the period of time in the Fig. 2

\section{CONCLUSION}

Soyabean is an important dietary component which contains abundant amount of proteins or amino acids required by human body for normal growth and maintenance. In this project, isolation of soya proteins was carried out by extraction with $0.01 \mathrm{~N}$ sodium bicarbonate and thereafter homogenization, centrifugation and dialysis of extract against Tris buffered saline solution. These proteins were characterized qualitatively by electrophoresis and quantitatively by Biuret assay method. Biuret assay method is an effective method to quantify amount of protein in given sample. . Amino acids present in the isolated protein were identified and quantified using standard or marker amino acids. The stability study of isolated soya proteins was carried out in simulated gastric fluid (SGF) and simulated intestinal fluid (SIF), prepared according to protocol specified in USP. These proteins were quantified by Biuret assay method after respective time interval in above specified fluids. The soya proteins were found getting hydrolyze in SGF after 5 minutes and in SIF within one hour. Thus in-vitro stability study of proteins in simulated fluids is an effective 
approach and alternative to animal model for bio-stability assessment.

\section{ACKNOWLEDGMENT}

We thank Dr. H. N. More, Principal, Bharati Vidyapeeth College of Pharmacy, Kolhapur;

\section{REFERENCES}

1. Lasztity $\mathrm{R}$, Petro-Turza $\mathrm{M}$ and $\mathrm{T}$ Foldes History of Food Quality Standards, In Food Quality Standards [Lasztity R Ed.], In Encyclopedia of Life Support Systems (EOLSS), EOLSS Publishers. Oxford, UK, 2004: VolumeIII, 2-11.

2. Lee, Jookyeong. (2011). Soy protein hydrolysate; solubility, thermal stability, bioactivity, and sensory acceptability in a tea beverage. Retrieved from the University of Minnesota Digital Conservancy, http://hdl.handle.net/11299/117047.

3. Montgomery, K.S. Soy Protein. The Journal of Perinatal Education. 2003; Vol-12, 42-44.

4. Sandra Maria Barbalho and Flávia, M. V. Farinazzi-Machado. Soybean: Food or Remedy? Soybean and Nutrition, Prof. Hany El-Shemy (Ed.), ISBN: 978953-307-536-5, InTech, Available from:

http://www.intechopen.com/books/s for providing required facilities to carry out this research work.

\section{ABBREVIATIONS:}

SGF Simulated Gastric Fluid; SIF, Simulated Intestinal Fluid; GIT, Gastro-Intestinal Tract.

oybean-and-nutrition/soybean-foodor-remedy.

5. Ryan, M., McEvoy, E., Duignan, S., Croaley, C., Fenelon, M., O'Callaghan, D.M., FitzGerald, R.J. Thermal stability of soy protein isolate and hydrolysate ingredients. Food Chemistry, 2008; 108. 503-510.

6. Zieve, D. (2009). In Protein in diet: MedlinePlus Medical Encyclopedia. Retrieved from http://www.nlm.nih.gov/ medlineplus/ency/article/002467.htm

7. Centers for Disease Control and Prevention. (2009).

8. In Nutrition for Everyone: Basics: Protein.

9. Osterweil, N. (2004). In The Benefits of Protein. Retrieved from http://www.webmd.com/fitnessexercise/guide/benefitsprotein.

10. Cogan, U., Yaron, A., Berk, Z., Mizrahi, S. Isolation of Soybean Protein: Effect of Processing Conditions on Yield and Purity. Journal of the American Oil Chemist's Society. 1967; 44: 321. 
11. Elias S. Food Engineering. 1979; 51(10), 81.

12. Kolar C.W., Richert, S.H., Decker, C.D., Steinke, F.H., Van der Zanden, Isolated Soy Protein in "New Protein Foods", R.J. A.M. Altschul and H.L. Wilke eds. Academic Press Inc. Orlando, Florida. (1985).
13. Mizrahi S., Berk, Z., Cogan, U. (1967). Isolated Soybean Protein as a Banana Spray-drying Aid. Cereal Science Today. 1967; 12: 322.

How to cite this article:

Sadaf et al., Isolation, characterization, analysis and stability study of soya proteins in simulated fluids. Int. J. Adv. Pharm. Biotech., 2018; 4(1): 25-30. 